Lect. univ. dr. Bogdan Dima

Facultatea de Drept, Universitatea din București

Președinte Asociația Centrul pentru Analize Strategice

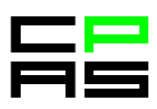

\title{
Cât durează starea de urgență?
}

Rezumat: În acest articol voi prezenta procedura pentru adoptarea decretului prezidențial pentru instituirea stării de urgență în conformitate cu art. 93 din Constituție și cu prevederile OUG nr. 1/1999 privind regimul stării de asediu și regimul stării de urgență (OUG nr. 1/1999). Nu este reglementat nicăieri un termen maxim limită pentru durata stării de urgență. Cu toate acestea, există o regulă esențială în OUG nr. 1/1999 conform căreia prelungirea stării de urgență se poate dispune de către Președinte doar cu acordul Parlamentului și numai pentru perioade consecutive de 30 de zile. Această garanție legală împotriva abuzului de putere constituie un mecanism eficient de control și consens.

Cuvinte cheie: stare de urgență, durată, Președinte, Parlament, mecanism de control

\section{How Long Will Last the State of Emergency?}

Abstract: In this article, I shall present the procedure for issuing a presidential decree to institute the state of emergency in accordance with art. 93 of the Constitution, as well as with Emergency Ordinance no. 1/1999 concerning the regime of the state of siege state and the regime of the state of emergency (EOG no. 1/1999). There is no maximum time limit for the duration of the state of emergency. However, there is a fundamental rule provided by EOG no. 1/1999 according to which the prolongation of the state of emergency can be disposed by the President only with the consent of the Parliament, and only for short consecutive 30 days periods. This legal guarantee against abuse of power provides an efficient control and consensus building mechanism.

Key words: state of emergency, duration, President, Parliament, control mechanism

Cel puțin teoretic, de esența stării de urgență este să fie instituită pentru o perioadă limitată de timp. Practic, însă, istoria stărilor de excepție (indiferent cum s-au numit oficial - stare de război, de asediu, excepțională sau de urgență) ne arată că acestea durează cât este necesar.

Dintr-o perspectivă formal juridică, constituțională și legală, lucrurile sunt relativ clare: legea prevede care este durata stării de urgență, cine o instituie, cine o poate prelungi sau modifica, respectiv care sunt situațiile în care poate fi dispusă/prelungită/modificată. Dintr-o 
Lect. univ. dr. Bogdan Dima

Facultatea de Drept, Universitatea din București

Președinte Asociația Centrul pentru Analize Strategice

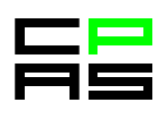

perspectivă a teologiei politice, lucrurile nu mai sunt deloc clare pentru că sunt influențate de cântecul fermecător, dar periculos al ideologiilor asumate.

\section{Durata stării de urgență}

Printre altele, art. 93 alin. 2 din Constituție prevede că Parlamentul funcționează pe toată durata stării de urgență. Constituția nu a prevăzut o anumită durată, o limită de timp maximă pentru starea de urgență. Însă, prin interpretare textualistă, ajungem la concluzia că termenul constituțional „durată” înseamnă o perioadă determinată de timp. Implică în mod necesar o limită temporală. O durată nu poate însemna o eternitate pentru că durata nu implică ideea de permanență, ci de secvență temporală.

În art. 5 al OUG nr. 1/1999 se prevede că starea de urgență se poate institui pe o perioadă de cel mult 30 de zile (calendaristice). În plus, art. 15 din această ordonanță de urgență prevede că, în funcție de evoluția situațiilor de pericol, Președintele României, cu încuviințarea Parlamentului, poate prelungi durata stării instituite și poate extinde sau restrânge aria de aplicare a acesteia. Prelungirile se dispun în condițiile prevederilor art. 5 (din OUG nr. 1/1999). Această ultimă prevedere a fost adăugată prin Legea nr. 453/2004. Ea nu exista în forma inițială a OUG nr. 1/1999. În această formă inițială nu se prevedea durata pentru care se putea dispune prelungirea stării de urgență; teoretic starea de urgență putea fi prelungită de Președintele României, cu încuviințarea Parlamentului, pentru o perioadă nedeterminată.

Noua reglementare instituită în 2004 prin Legea nr. 453/2004 este aparent contradictorie. Pe de o parte, stabilește o durată limitată în timp a stării de urgență instituită prin decret al Președintelui și încuviințată de Parlament (30 de zile). Pe de altă parte, stabilește posibilitatea prelungirii stării de urgență pentru perioade succesive de câte 30 de zile, dar fără să prevadă o perioadă maximă finală. Ca atare, durata stării de urgență este și nu este limitată în timp.

În realitate, efectul practic al acestor dispoziții legale din art. 15 al OUG nr. 1/1999 este acela că Președintele României nu poate dispune pe termen nelimitat starea de urgență fără ca Parlamentul să încuviințeze prelungiri succesive din 30 în 30 de zile. Din această perspectivă, dispozițiile din art. 15 al OUG nr. 1/1999 așa cum au fost modificate de Legea nr. 453/2004 sunt conforme cu Legea fundamentală și asigură un control parlamentar regulat asupra deciziei Președintelui de a menține prin prelungire starea de urgență care, așa cum am văzut deja, implică serioase restricții ale exercițiului unor drepturi și libertăți.

\section{Procedura prelungirii stării de urgență}

Așa cum este formulat, art. 15 din OUG nr. 1/1999 poate ridica serioase probleme de interpretare cu privire la procedura prelungirii stării de urgență. Dacă ținem cont de faptul că avem o stare de urgență instituită în contextul unei coabitări dintre un executiv de o anumită 
Lect. univ. dr. Bogdan Dima

Facultatea de Drept, Universitatea din București

Președinte Asociația Centrul pentru Analize Strategice

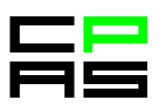

culoare politică și un legislativ dominat de partide care se opun executivului, conținutul art. 15 poate constitui sursa unui scandal pe cât de intens, pe atât de inutil.

Astfel, conform respectivului articol, „în funcție de evoluția situațiilor de pericol, Președintele României, cu încuviințarea Parlamentului, poate prelungi durata stării instituite și poate extinde sau restrânge aria de aplicare a acesteia". Întrebarea cheie este următoarea: încuviințarea Parlamentului este anterioară sau ulterioară emiterii decretului Președintelui României de prelungire a stării de urgență?

O interpretare strict gramaticală, care ține cont de poziția în frază a sintagmei „cu încuviințarea Parlamentului" conduce la ideea că această încuviințare trebuie să fie anterioară emiterii decretului Președintelui României privind prelungirea stării de urgență. Mai mult, într-o interpretare aparent logică s-ar putea spune că Parlamentul, tocmai pentru că are obligația constituțională să funcționeze pe toată durata stării de urgență pe care a încuviințat-o, ar trebui să se pronunțe în prealabil cu privire la prelungirea respectivei stări de urgență. Nu în ultimul rând, un al treilea argument ar fi acela că art. 15 din OUG nr. 1/1999 nu prevede niciun termen pentru încuviințarea de către Parlament a prelungirii stării de urgență prin decret al Președintelui. Ca atare, ar rezulta că încuviințarea Parlamentului nu poate să fie decât prealabilă deciziei Președintelui de a prelungi starea de urgență.

Totuși, argumente juridice pe care personal le consider mult mai solide justifică o interpretare contrară.

În primul rând, dacă legiuitorul ar fi dorit să stabilească momentul la care se acordă încuviințarea prelungirii stării de urgență (înainte sau după emiterea decretului prezidențial), ar fi trebuit să prevadă acest lucru în mod expres. De exemplu, așa cum a făcut-o în art. 16 alin. 2 din OUG nr. 1/1999 - „în cazul înlăturării situațiilor de pericol, înainte de expirarea termenului stabilit, încetarea aplicării măsurii excepționale se dispune prin decret, cu încuviințarea prealabilă a Parlamentului". Astfel, doar atunci când avem de-a face cu încetarea stării de urgență, încetarea nu poate fi dispusă de Președintele României prin decret decât în condițiile în care Parlamentul încuviințează acest lucru în prealabil, iar nu ulterior emiterii decretului.

În al doilea rând, art. 15 din OUG nr. 1/1999 nu prevede doar posibilitata prelungirii stării de urgență. Art. 15 prevede și posibilitatea extinderii sau restrângerii ariei de aplicare a stării de urgență. Astfel, în funcție de evoluția situațiilor de pericol care au determinat inițial instituirea stării de urgență, Președintele și numai Președintele se bucură de o largă putere discreționară de a decide extinderea sau restrângerea măsurilor necesare care trebuie luate raportat la situația de fapt existentă. Dacă această situație de fapt reclamă de urgență luarea unei măsuri noi, care trebuie adăugată măsurilor deja dispuse prin decretul de instituire a stării de urgență, atunci Președintele are obligația de a reglementa respectiva măsură într-un nou decret, cât mai repede, urmând să supună acestă decizie încuviințării Parlamentului. În mod similar, dacă situația de fapt 
Lect. univ. dr. Bogdan Dima

Facultatea de Drept, Universitatea din București

Președinte Asociația Centrul pentru Analize Strategice

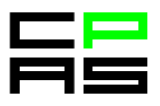

reclamă restrângerea sau eliminarea unora dintre măsurile restrictive privind drepturile și libertățile fundamentale care au fost dispuse inițial, atunci Președintele are obligația să stabilească acest lucru cât mai repede, prin decret, urmând ca măsura să fie încuviințată de Parlament. În consecință, tocmai pentru că art. 15 nu face nicio distincție între măsurile de prelungire, extindere sau restrângere a stării de urgență, ceea ce contează cu adevărat este ca decizia să fie luată cât mai rapid, atunci când este necesară, de către titularul deciziei, Președintele României, urmând să fie supusă încuviințării ulterioare a Parlamentului.

În al treilea rând, chiar dacă art. 15 nu prevede un termen pentru încuviințarea prelungirii stării de urgență de către Parlament, acesta nu poate fi altul decât cel stabilit în Constituție și în art. 12 din OUG nr. 1/1999 pentru instituirea stării de urgență, anume în cinci zile de la data luării respectivei măsuri. $\mathrm{O}$ astfel de interpretare se bazează pe scopul urmărit de legiuitor. În cazul art. 15 din OUG nr. 1/1999, scopul urmărit de legiuitor este același cu scopul urmărit de legiuitorul constituant în art. 93 alin. 1: de a a asigura cea mai mare rapiditate în luarea măsurilor necesare pe care le implică starea de urgență.

\section{O atenționare necesară}

Indiferent de argumentele constituționale și legale cu privire la durata și procedura de prelungire a stării de urgență, este extrem de important să fim cu mare băgare de seamă ca această situație excepțională să nu se permanentizeze. Dacă starea de urgență s-ar permanentiza, atunci ar deveni o stare de normalitate în care nu mai este prioritar sfârșitul acesteia. Important pentru toate instituțiile statului și pentru membrii societății este ca prioritară să rămână epuizarea cu rapiditate a stării de urgență, pentru a rămâne ceea ce este, o stare de excepție temporară.

Să nu ne lăsăm amăgiți, păcăliți sau să rămânem speriați de impactul traumatic al stării de fapt prin care trecem. Starea de urgență este periculoasă pentru orice societate democratică, cu atât mai mult pentru societățile democratice neconsolidate. Starea de urgență invadează ordinea constituțională care avea menirea să garanteze drepturi și libertăți fundamentale pentru a institui cu prioritate restricții și obligații. Scopul inițial declarat al stării de urgență este nobil, acela de a salva însăși societatea de la un pericol actual sau iminent care îi pune în pericol existența. Dar, dacă durează prea mult, scopul nobil se transformă într-o justificare a autoritarismului. Puterea învățată odinioară cu limite instituționale se dezvață de obiceiul de a se lăsa temperată prin instituții și cu greu va mai accepta să fie, din nou, controlată și limitată.

Puterea lăsată liberă prea mult timp nu mai poate fi îmblânzită ușor. De aceea, nu este suficient ca în starea de urgență măsurile derogatorii cu privire la răstrângerea drepturilor și libertăților să fie proporționale și în legătură strictă cu situaţia care le impune, aspect care deja a început să ridice câteva probleme serioase. Însăși măsura instituirii stării de urgență trebuie să rămână proporțională cu situația care a determinat-o. Și singura garanție instituțională pe care o 
Lect. univ. dr. Bogdan Dima

Facultatea de Drept, Universitatea din București

Președinte Asociația Centrul pentru Analize Strategice

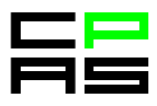

avem în acest sens și în acest moment este doar această secvențialitate de 30 de zile, care forțează instituțiile cele mai reprezentantive (Președintele și Parlamentul) să negocieze și să cadă de acord cu privire la prelungirea, modificarea sau încetarea stării de urgență. Dacă pierdem aceste garanții de negociere și control reciproc, putem să sfârșim, ca să îl parafrazez pe Agamben, într-un teritoriu al nimănui, la intersecția dintre drept care impune și act politic discreționar care decide.

Materialul a fost publicat pe G4media.ro și preluat ulterior în revista online a Facultăţii de Drept, AUBD - Forum juridic nr 1/2020. 